\title{
Community Policing: Broken Windows, Community Building, and Satisfaction with the Police
}

\author{
Robert M. Lombardo \\ Loyola University Chicago, rlombar@luc.edu \\ Todd Lough \\ Western Illinois
}

Follow this and additional works at: https://ecommons.luc.edu/criminaljustice_facpubs

Part of the Criminology and Criminal Justice Commons

\section{Recommended Citation}

Lombardo, R., \& Lough, T. (2007). Community Policing: Broken Windows, Community Building, and Satisfaction with the Police. Police Journal, 80(2), 117-140. http://dx.doi.org/10.1350/pojo.2007.80.2.117

This Article is brought to you for free and open access by the Faculty Publications and Other Works by Department at Loyola eCommons. It has been accepted for inclusion in Criminal Justice \& Criminology: Faculty Publications \& Other Works by an authorized administrator of Loyola eCommons. For more information, please contact ecommons@luc.edu.

\section{(c) $($ () $\ominus$}

This work is licensed under a Creative Commons Attribution-Noncommercial-No Derivative Works 3.0 License. (c) Vathek Publishing, 2007. 


\section{COMMUNITY POLICING: BROKEN WINDOWS, COMMUNITY BUILDING, AND SATISFACTION WITH THE POLICE}

The concept of community policing dominates the law enforcement profession today. One would be hard pressed to find an advertisement for a police chief's position that does not require a thorough understanding of this method of policing. Like the Kansas City preventive patrol experiment and the Rand report on the criminal investigation process, the call for community policing has led to dramatic changes in the way that police carry out their responsibilities. In spite of its popularity, there have been a number of challenges to community policing from social scientists who are particularly concerned about the 'broken windows' model of policing. These challenges have not been received well by the law enforcement community, which argues that sociologists are wedded to the idea that crime is caused by the structural features of capitalist society, including economic injustice, racism, and poverty. The purpose of this article is to bridge the gap between these two positions. Yes, there is a place for community policing, and, yes, social problems do contribute to crime. The article starts by reviewing the development of community policing in the United States. An analysis of the theoretical constructs that support community policing then follows. Finally, we argue that there is sound theoretical evidence to support community policing, particularly those programmes that improve citizen satisfaction with the manner in which police carry out their responsibilities.

\section{Community Policing}

Community policing is a law enforcement philosophy based on the concept that police officers and private citizens, working 
together in creative ways, can help solve contemporary community problems related to crime, fear of crime, social and physical disorder, and neighbourhood conditions (Tronjanowicz et al., 1998). Police departments have attempted to institute community policing in a number of ways including foot patrol, bicycle patrol, police substations, citizen police academies, community meetings, newsletters, surveys, crime analysis, and working with other government agencies to find non-traditional solutions to crime problems. How it looks in practice varies from jurisdiction to jurisdiction in response to the individual needs of each community. Community policing is said to have three core elements: citizen involvement, problem solving, and decentralisation (Skogan, 2006). All are related, but citizen involvement is especially crucial because it is the basis of the theoretical foundation of community policing.

The concept of community policing evolved over time. Rising crime rates in the early 1960s led to a recognition that changes needed to occur in the US police service. This concern was highlighted by the President's Commission on Law Enforcement and the Administration of Justice (1967), which called national attention to the need to improve the components of the criminal justice system. The need for change may have come as a surprise to many police officials. Progressive police administrators, throughout the nation, had been working diligently, since the repeal of Prohibition, to modernise their police departments. The introduction of the principles of scientific management and the professionalisation of the rank and file were seen as the keys to successful police operations. Reviews of the manner in which police handled Viet Nam war protestors and civil rights demonstrators told a different story. Police handling of the 1968 democratic convention in Chicago was labelled a 'police riot' by investigators from the National Commission on the Causes and Prevention of Violence because of the manner in which Chicago Police responded to acts of civil disobedience by antiwar protestors. The 1968 National Commission on Civil Disorders (Kerner, 1968) concluded that the riots that had occurred in Los Angeles (1965), Chicago (1966), Newark (1967), and Detroit (1967) were not only the result of systematic discrimination, but also poverty, unemployment, poor education, inadequate housing, poor health care, and systematic police bias and brutality! This finding, in particular, led to the recognition that police departments were often isolated and alienated from an important segment of their communities: those that needed their services most. 
The isolation that police felt from the communities they served has been attributed to the very reforms that have driven police modernisation. The history of policing is generally divided into three time periods: the political, the professional, and the community policing eras (Kelling \& Moore 1988). During the political era (1840-1930), police agencies were dominated by local political leaders, poorly organised, and rampant with corruption. The professional era of policing (1930-1970) sought to remedy these problems by removal of the police from politics, the introduction of the principles of scientific management, and the implementation of advanced technology including the telephone and police radio. In addition, police departments, throughout the United States, adopted O. W. Wilson's strategy of motorised patrol, rapid response to calls for service, and retrospective investigation of crime. It was these very reforms that sparked the community policing revolution. Motorised patrol and the command-and-control function of the police radio dispatcher came to be viewed as the direct causes of the separation of the police from the community.

In response to the national call to improve policing, university researchers and police officials began evaluating police operations. Three of their studies had a profound effect on the manner in which police carried out their responsibilities and were particularly important to the evolution of community policing. The first, the 1973 Kansas City Preventive Patrol Experiment (Kelling et al., 1974), found that traditional routine police patrol in marked vehicles did not affect the level of crime. That same year, the Rand Corporation undertook a nationwide study of detective practices in order to assess the value of criminal investigations. The study concluded that detective work played a minor role in contributing to overall arrest rates and that much of a detective's time was consumed with administrative paperwork and interviewing witnesses in cases that had little likelihood of being solved (Greenwood \& Petersilia, 1975). Finally, the Kansas City Response Time Study (1977) found that faster police response time did not necessarily lead to more arrests. This was due in large part to the fact that victims often did not immediately report crime to the police.

Two other developments contributed directly to the evolution of community policing. The first, team policing, assigned responsibility for all police activity in a specific geographic area to a permanent team of officers including the integration of patrol and follow-up investigative activities (Sherman et al., 1973). Team policing was seen as a way to address the problems 
of the over-centralisation of police agencies and the increasing sense of alienation felt by the community. Begun in Aberdeen, Scotland, team policing sought to hold a small group of officers responsible for crime in their area of assignment. Although received with great enthusiasm by the 1967 President's Commission on Law Enforcement and the Administration of Justice, team policing never fulfilled its promise. One of the main reasons for this was the practical limitations of the integration of different areas of police specialisation, though, many police departments have adopted the team policing requirement of permanency of watch and geographic assignment.

Another advancement that contributed to the evolution of community policing was the development of problem-oriented policing. Claiming that they were so preoccupied with running their organisations, Herman Goldstein (1979) argued that the police had lost sight of their primary purpose of crime control. Like a bus passing riders to keep on schedule, police departments were spending too much time on efforts to improve internal management and not enough time on efforts to improve crime control. To remedy the problem, Goldstein recommended that police break down categories of crime and disorder into discrete problems and develop specific responses to each one. Problem-oriented policing was given a boost by the development of 'routine activities theory'. Published the same year as Goldstein's call for police problem solving, routine activities theory argued that three things were necessary for crime to occur: a motivated offender, a suitable target, and the absence of a capable guardian (Cohen \& Felson, 1979). Change one of these conditions and the offence will not occur. Routine activities theory provided law enforcement with the analytical means to study crime problems. The theory also provided law enforcement with the ability to develop strategies to address these problems, whether through traditional law enforcement mechanisms or by working with other government agencies.

The concept of community policing is sometimes difficult to define. In fact, the Committee to Review Research on Police Policy and Practices of the National Research Council (National Research Council, 2004) concluded that community policing is simply too amorphous a concept to submit to empirical evaluation. Xu, Fiedler, and Flaming (2005), however, may have solved this problem. They argue that the purpose of community policing is to expand the police role to include responsibility for the elimination of the social conditions that cause crime. While the professional model viewed police as law enforcement agents, 
community policing argues that the police should look beyond the law enforcement model to identify the conditions that generate crime and identify solutions to eradicate it. This new way of thinking is intended to look at crime in a more holistic view. For community policing, fighting crime is not an end in itself, but a means to the goal of eliminating the problems that cause crime. Effective policing should not only apprehend criminals, but also eliminate the social conditions that breed crime. By eliminating the conditions that cause crime, police can prevent future crime, thus reducing the total number of criminals in society: something that the traditional incident-oriented approach cannot do.

The idea that the police can address the 'root causes' of crime is a lot to expect from a government agency that is not equipped to carry out society-wide public policy reforms. Can the police realistically be expected to eliminate poverty and improve access to education as a means to control crime? Probably not, but in the words of $\mathrm{Xu}$, Fiedler, and Flaming (2005) they can (and have been expected to) participate in crime prevention through socialisation and social learning. That is, through community policing, they can be expected to increase positive stimuli and normative reinforcement, especially in the lives of young people, by interfacing with people on a regular basis, promoting community norms, providing moral guidance, and reinforcing socially acceptable behaviours through activities jointly sponsored by the police and the community. Although police have engaged in these activities for years, it is only recently that they have become the subject of theoretical analysis by the academic community.

\section{Theoretical Explanations}

American criminology rests squarely on social structural explanations of crime and the impact that a community has on regulating the conduct of its members. Community policing asks citizens to assume responsibility for crime by reporting crimes promptly to the police and by cooperating as witnesses when crimes occur. In order to ensure citizen cooperation, police have attempted to take responsibility for mobilising individuals and organisations around crime prevention through various community police programmes, including community meetings that seek to increase favourable contacts between the police and the public. Sociologists envision that these efforts will help to increase the informal social control mechanisms inherent in communities that have been lost in neighbourhoods besieged by 
crime and disorder, thus enabling residents to contribute to maintaining social control.

Two theoretical constructs underlie most community policing programmes: 'broken windows' theory and the 'community implant' hypothesis. Both are grounded in social disorganisation theory and both argue that there is a direct relationship between distressed communities and crime. Defined by Thomas and Znaniecki (1980) as a decrease in the influence of existing rules of behaviour upon individual members of a group, social disorganisation argues that there is a direct relationship between higher rates of deviance and the increased complexities of urban life. Shaw and McKay (1942) used the work of Thomas and Znaniecki to formulate a structural theory of crime. Supported by 30 years of research in Chicago, they argue that poor neighbourhoods, inhabited by heterogeneous and residentially unstable groups, are more likely to lack social organisation and, as a result, experience higher rates of juvenile delinquency. Although Shaw and McKay's theory was formulated more than fifty years ago, during a time of massive immigration to Chicago and other American cities, their findings are still relevant today. William Julius Wilson (1987), also studying the city of Chicago, argues that the de-industrialisation of American society has led to the establishment of a new set of structural constraints that has continued to fuel social disorganisation. Communities suffering from increased unemployment, poor educational opportunities, and residential immobility also lack the social organisation needed to control delinquent and criminal behaviour.

In her influential book, The Social Sources of Delinquency, Kornhauser (1978) redefined social disorganisation as the inability of a community social structure to realise the common values of its members and to maintain effective social controls. Community policing advocates such as Rosenbaum (1987) argue that if crime is the result of social disorganisation, police departments should work to improve social control by strengthening community ties and by encouraging behaviours that provide a basis for regulating conduct; in essence, work with communities to help them regulate the conduct of their members. A common methodology used by police agencies to improve social control in community areas is order-maintenance policing based on what has come to be known as broken windows theory.

\section{Broken Windows Theory}

Broken windows theory is a direct outgrowth of the Newark, New Jersey, Foot Patrol Experiment, in which foot patrol was 
reintroduced into community areas in an effort to reduce crime (Kelling, 1981). Although foot patrol did not have a direct effect on crime, citizens felt safer and developed a more favourable opinion of the police. In addition, the officers themselves expressed greater satisfaction with their work. How was this so? Citizens felt safer because fear of crime was reduced, that is fear of being bothered by disorderly people: drunks, panhandlers, addicts, prostitutes, gangs, and rowdy teens. It has been argued that the movement towards professionalism had downgraded order maintenance as a police concern and concentrated law enforcement activities on more serious violations (Kelling \& Moore, 1988). In addition, foot patrol had come to be viewed as an unproductive use of police manpower. The New Jersey experience provided a new justification for a return to foot patrol as a legitimate use of police resources and highlighted the importance of fear reduction strategies as well.

Broken windows theory is based on the assumption that disorder and crime are linked in a developmental sequence. If a window in a building is broken and left unrepaired, so the argument goes, all the rest of the windows will soon be broken as well. The unrepaired window is a signal that no one cares and so breaking more windows will not result in official sanction. This type of vandalism can occur anywhere once the sense of mutual regard and the obligations of civility are lowered by actions that seem to signal a lack of common concern. Broken windows theory was introduced in an Atlantic Monthly article by Wilson and Kelling in 1982 and has since become a driving force in community policing programmes, because of the belief that untended behaviour leads to the breakdown of community controls and crime. Wilson and Kelling (1982) argue that neighbourhoods where property is abandoned, weeds grow, windows are broken, and adults stop scolding rowdy children cause families to move out and unattached adults to move in. Fights occur, litter accumulates, people drink on the public way, and panhandlers begin to approach pedestrians. Graffiti proliferates, suggesting that the area is uncontrollable, and the fear of crime increases. In response, people begin to use the streets less, causing the area to become vulnerable to criminal invasion. The withdrawal of the community leads to increased drug sales, prostitution, and mugging.

The broken windows hypothesis was tested by Skogan (1990) in his book Disorder and Decline. Collecting data from 40 urban neighbourhoods, Skogan concluded that disorder increases the level of serious crime. He identified two types 
of disorder: physical disorder, which includes the presence of junk and trash in vacant lots, boarded-up buildings, vandalism, graffiti, and stripped and abandoned cars; and social disorder, which includes the presence of gangs, prostitutes, panhandlers, drunks, and open gambling and drug use. Skogan also presented evidence that disorder needed to be distinguished from serious crime, further strengthening the call for order maintenance policing. His work also supported social disorganisation theory. Skogan's findings established that poverty, instability, and the racial composition of a neighbourhood were strongly linked to area crime, but a substantial portion of that linkage was through disorder.

Kelling and Coles (1996) provided further support for broken windows theory in their book Fixing Broken Windows. In it, they argue that the police needed to pay more serious attention to disorder and order maintenance policing. Arguing that the law enforcement model had fixed police resources on felony crime, the authors conclude that order maintenance issues had reached a critical mass, causing fear of crime to increase. Although consistent with the ideology that non-violent deviance should be tolerated in the interest of liberty, the decriminalisation of alcoholism, increased numbers of homeless people, and the deinstitutionalisation of the mentally ill all increased disorder and fear of crime in neighbourhood areas. Kelling and Coles offered the dramatic decrease in crime in New York City as evidence of the importance of order maintenance policing. Through strict enforcement of incivilities and misdemeanour offences, New York, he argued, solved much of its crime problem. So substantial was the decrease in crime that Silverman (1999) reported that the decrease in New York City alone accounted for $60 \%$ of the national decline in crime.

There have been a number of challenges to what has been described as the 'New York Miracle' and to broken windows theory itself. In fact, Harcourt (1998) wrote in the Michigan Law Review that there was no empirical evidence to support the theory. His position was later expanded in his 2001 book entitled The Illusion of Order: The False Promise of Broken Windows. In 1993, New York City began the 'quality of life initiative', an order maintenance strategy targeting minor misdemeanour offenders premised on the broken windows concept. The principal scientific justification for the initiative was the nexus between disorder and crime established by Skogan's book Disorder and Decline. By eliminating minor misdemeanours and disorderly behaviour, New York thought that it could deter 
serious crime. Harcourt defined this thesis as the 'social influence' conception of deterrence. As mentioned earlier, New York offered its falling crime rate as evidence that broken windows policing was working. Harcourt, however, challenged this position by arguing that there were other factors that contributed to the falling crime rate, including an increase of 3,000 police officers, favourable economic conditions, a reduction in the 18-24-year-old population, an increased number of persons imprisoned, and the fact that the crime rate was decreasing all over the country, and not just in New York City. Harcourt titled his explanation for the decreasing New York crime rate 'enhanced surveillance'. Enhanced surveillance, in the form of increased law enforcement, provided a reason for investigating persons suspected of committing crimes. Harcourt argued that it was not by a reduction in litter, fixing broken windows, or eliminating graffiti that crime decreased, but the result of increased law enforcement efforts on the part of the police.

Harcourt (1998) also challenged the methodological integrity of Skogan's original analysis. In replicating Skogan's study, Harcourt found that $30 \%-40 \%$ of the data were missing and that five of the sample neighbourhoods had excessively influenced the occurrence of robbery. Once these areas were controlled for, the relationship between robbery and disorder disappeared. These findings led Harcourt to conclude that the data did not support the claim that reducing disorder deters serious crime. In the end, Harcourt concluded that order maintenance policing did not uphold community values, but created community norms defining disorderly activities as criminal offences, activities that could be better handled by social service agencies.

Sampson and Raudenbush (1999) conducted research that provided what many believed was empirical support for Harcourt's position. Combining census data, police records, 3,500 resident surveys, and videotapes of more than 23,000 street segments in Chicago, the authors found that, contrary to broken windows theory, the relationship between public disorder and crime was spurious. Graffiti does not cause crime! Disorder and crime are both manifestations of the same explanatory process. They share common structural and social origins. The cause of crime is structural disadvantage and weak collective efficacy: the ability of a community to regulate conduct. The authors add that the fascination in public policy circles with cleaning up disorder through law enforcement techniques is simplistic and misplaced in terms of directly fighting crime. In fact, their data demonstrate that crime and disorder are not 
highly correlated and that neighbourhoods high in disorder do not have higher crime rates than neighbourhoods low in disorder. The authors, however, do not totally discount the usefulness of disorder in predicting crime. Rather than arguing that disorder is the direct cause of crime, the authors argue that disorder is part and parcel of crime itself. Social disorder and incivilities are evidence that crime is occurring. Therefore, public disorder crimes and predatory crimes are manifestations of the same explanatory process, although at different ends of the seriousness scale. Because disorder is a manifestation of crime-relevant mechanisms, Sampson and Raudenbush argue that improved collective efficacy should reduce disorder and violence by disempowering the forces that produce both.

Further support for the attack on broken windows theory came from a book published by Taylor (2001) entitled Breaking away from Broken Windows. The object of Taylor's work was to determine the origin of incivilities and determine whether or not they eroded urban life over time. Taylor found that there were two types of reactions to crime: fear as a psychological concept and fear as an ecological concept. Fear as a psychological concept is a reflection of an individual's perception of crime. Analysing data collected in Baltimore, Maryland, Taylor concluded that fear, as a psychological concept, overshadows fear as an ecological concept. Some people are more fearful than others. Therefore, zero-tolerance, order-maintenance police strategies, aimed at reducing fear of crime, may be misdirected and should not be adopted axiomatically. Incivilities are better interpreted as a result of an economically disadvantaged neighbourhood, rather than as a symptom of a disorderly or disorganised neighbourhood, and that crime fighting is more important than grime fighting for long-term reductions in crime.

Broken windows policing was also challenged by declining crimes rates in San Francisco. A study conducted by the California-based Center on Juvenile and Criminal Justice (2002) demonstrated that during the time that New York City was being held up as a national model, similar rates of decline were occurring in other cities around the country, the most notable of which was San Francisco. Long derided by conservatives for its alternative crime policies, San Francisco registered reductions in crime that equalled or exceeded comparable cities and jurisdictions, including New York City, in spite of having adopted less strident law enforcement policies that reduced arrests, prosecutions, and incarceration rates. In fact, San Francisco's crime 
reduction coincided with declining misdemeanour and felony arrest rates and declining prison commitments.

The backlash against broken windows policing is not shared by all criminologists. Thacher (2004) argues that this backlash focuses too narrowly on broken windows theory in its assessment of order maintenance policing's effect on serious crime, and that some forms of order maintenance policing are intrinsically valuable. Even if we cannot establish a direct causal relationship between crime and disorder, Thacher believes that order maintenance policing may create desirable outcomes, but we have not identified these outcomes because of a lack of ethnographic research and qualitative study. He also cautions against the dangers of 'strong causal reasoning' policy analyses that rely on claims that an intervention will have large, indirect effects on some important social problem, when only a small amount of variation in the dependent variable is explained.

The caution against strong causal reasoning works both ways. There have been a growing number of studies that reject the attacks against broken windows theory and provide evidence of the direct effects of order maintenance policing on crime (Corman \& Mocan, 2002; Worrall, 2002; Xu et al., 2005). These studies, however, could also be criticised for their reliance on complex causal models whose ability to predict variation in the dependent variable is limited. Xu, Fiedler, and Flaming (2005) provide the best example. They not only develop a causal model that supports broken windows policing, but also caution the reader about their findings. For example, the authors conclude that their study has its limitations because: they were unable to distinguish between individual-level effects and communitylevel effects; they did not have adequate access to community policing variables, and the external validity of their study had its limitations. These comments are not meant to be a criticism of their work, but to show the complex nature of the topic under study. In fact, their study provides one of the most robust reviews of broken windows policing available.

The legitimatisation of order maintenance policing has brought community policing full circle. The reform era of policing established police as professional law enforcers and crime fighters. This professional model led to the establishment of aggressive patrol strategies, which often placed police in direct confrontation with minority communities. Community policing sought to remedy these problems and re-establish communication between the police and the public. Broken windows policing, however, has broadened aggressive patrol strategies by 
extending them to include ordinance and misdemeanour offences; an ironic outcome for a programme that was created to improve police-community relations.

In the end, it must be concluded that empirical support for broken windows theory and order maintenance policing, in spite of their popularity, is mixed. In fact, sceptics like Harcourt (1998), have gone as far as to say that: 'Broken windows policing is a harmful, conservative philosophy masquerading as pragmatic and progressive public policy.' In response to critics, Bratton and Kelling (2006) argue that there was nothing in the original broken windows article about zero-tolerance policing, and that the essence of the police role in maintaining order is to reinforce the informal control mechanisms of the community itself by collaborating with citizens and the better training of police officers in the use of discretion. Such an approach is the basis of the community implant hypothesis.

\section{Community Implant Hypothesis}

The second major theoretical construct underlying community policing programmes is the community implant hypothesis. Sociologists have long argued that one of the main reasons for high levels of crime is the lack of informal social control in community areas. The community implant hypothesis argues that informal social control can be implanted by collective citizen action in neighbourhoods where social control is naturally weak or non-existent. The term community implant hypothesis was first used by Rosenbaum (1987) in his essay entitled 'Theory and Research Behind Neighborhood Watch'. This approach has also been described as 'community building' by Mastrofski, Worden, and Snipes (1995). Community building is a process by which the police strengthen the capacity and resolve of citizens to resist crime by building positive relationships with community residents.

Social control generally refers to the capacity of a group to regulate its members. It involves the use of rewards and punishments to ensure that members of a society obey group norms. Formal social control is derived from written rules and laws and is enforced by the police and the courts. Informal social control is based on custom and social norms and is enforced by the citizenry through behaviours such as surveillance, verbal reprimand, rejection, warning, and other pressures to encourage conformity. The question for community policing then becomes whether the police, working with the community, can implement informal social control in socially disorganised community areas. 
This strategy has in fact been adopted by a number of police departments as the basis of their community policing programmes in the form of beat meetings and greater community involvement in problem-solving activities, and is the basis of the community policing argument that citizens are co-producers of public safety.

Lyons (1999), in his book The Politics of Community Policing, argues that a core assumption in the logic of community policing is that innovative police strategies can mobilise the informal mechanisms of social control embedded within community life. This vision, inspired by the Newark foot patrol experiment, calls for a return to the days when foot patrol officers knew residents by name and, because of the relationships thus established by these officers, citizens would provide information to assist the police in establishing neighbourhood order: a return to 'Mayberry' (idyllic small-town life) where the familiarity of community life contributed to the establishment of social order. It should be noted, however, that not everyone agrees that there is an earlier time in policing worth returning to. Walker (1984) argues that the good old days of the friendly cop on the beat never existed, and that police departments during the political era were replete with corruption and evasion of duty.

In spite of the popularity of programmes that utilise the community-building approach, there is little empirical research to support the effectiveness of the community implant hypothesis. Although not aimed directly at testing this approach, two important evaluations cast doubt on the ability of community and government efforts to increase social control at the community level and, much less, have a direct impact on crime and delinquency. The first, the Chicago Area Project begun in the 1930s by Clifford Shaw, was developed to prevent juvenile delinquency by enhancing social control in community areas through the use of educational, recreational, and occupational opportunities for youth. In spite of its many individual successes, an evaluation of the initiative conducted by Finestone (1972) concluded that the project had not provided a method of coping with the most serious forms of delinquency in the areas of the city with the highest rates of criminality, which suggested that efforts at creating informal social control were ineffective.

The ability of community residents and government officials to increase social control in neighbourhoods was also tested by Skogan (1990), who argued that efforts at increasing the effectiveness of the local community to address crime and disorder have taken two approaches: identifying existing community 
organisations and encouraging them to make a greater commitment to the prevention of disorder and crime; and encouraging the formation of organisations in communities where viable opportunities for participation in anticrime activities do not appear to exist. Skogan tested both models. Four existing community programmes were studied in Chicago, and several new programmes were evaluated in Minneapolis. The evaluations were designed to test whether: (1) the programmes increased social interaction and mutual solidarity; (2) enhanced people's feelings of efficacy about individual and collective community action; (3) stimulated the residents' willingness to intervene in suspicious circumstances; and (4) whether the programmes encouraged the residents to take positive steps to prevent disorder and crime.

No programme was found to increase solidarity or social interaction. Nor did any of the programmes improve neighbourhood conditions. In Minneapolis, after two years of effort, residents of the programme areas did not see any improvement in measures of perceived disorder, physical decay, crime, or fear of crime, in spite of the fact that professional organisers were hired to mobilise their neighbourhoods around crime control issues. These findings raised important questions about the ability of community-organising efforts to affect the quality of life in neighbourhood areas. Skogan concluded by asking whether the programmes had failed or whether theory had failed.

The concern with theory failure may have been remedied by the introduction of the concept of satisfaction with the police. Research by Silver and Miller (2004), in the social disorganisation tradition utilising data collected by the Project on Human Development in Chicago Neighborhoods, found that community attachment and satisfaction with the police contribute significantly to neighbourhood levels of informal social control. The residents of communities that were satisfied with the ability of the police to control crime and maintain order were more likely to engage in activities to control youthful behaviour.

Increased satisfaction with the police is indeed one of the fundamental goals of community policing. If residents feel a greater sense of responsibility for maintaining order when they are satisfied with the police, police should work to create better relationships with the community. Based on the work of Silver and Miller (2004), it could be argued that efforts to 'implant' informal social control in urban neighbourhoods, where social control is naturally weak or non-existent, can be positively 
affected by improved police-community relations. Interestingly, Silver and Miller (2004) also offer a way to reconcile the debate over broken windows theory. Their research indicates that satisfaction with the police is strongly related to perceptions of social order including litter, graffiti, and public drinking. Residents of neighbourhoods characterised by visible signs of disorder hold police accountable for these conditions. Therefore, a promising strategy may be one that persuades residents that the police are willing to work with them to address these problems.

\section{What Does it All Mean?}

Research sponsored by the National Institute of Justice (2002) found that the biggest factor contributing to satisfaction with the police was the public's perceptions about the quality of their lives: their sense of safety. The second biggest factor in shaping opinions was direct contact with the officers: how police behave when they interact with citizens. These findings have two important implications. First, if citizens fear for their safety, broken windows policing can be an important strategy for reducing the signs of physical and social disorder that lead to increased levels of anxiety. Second, improving the quality of daily interaction between patrol officers and citizens may be the best possible way for a police department to improve public satisfaction with the police. Both of these findings are closely related. Rose and Clear (1998) found that police use of heavyhanded tactics can deplete already deficient relational networks. Therefore, aggressive order maintenance tactics, characteristic of zero-tolerance policing programmes, may work against satisfaction with the police, whether or not these programmes are successful at bringing order to the environment.

Research conducted by Resig and Parks (2000) found that much of the neighbourhood variation in satisfaction with the police can be explained by concentrated disadvantage. That is, there were fewer healthy, collaborative relationships between the police and neighbourhood residents in disadvantaged communities. This finding led them to question whether community policing could help the truly disadvantaged. In a separate study, Resig and Parks (2004), utilising data collected for the 1996 Project on Policing Neighborhoods, found that communities where citizens and their police have formed collaborative partnerships report fewer incivility problems and feel safer independently of structural disadvantage and crime, and that police-community collaboration partially mediates the influence of concentrated disadvantage on neighbourhood quality of life. 
Community policing therefore can help residents of poor, crimeinfested neighbourhoods.

Where does all this leave the community implant hypothesis? The original vision of returning to the days of the cop on the beat has never materialised. What has materialised, at least in one Chicago neighbourhood, is a new form of social organisation, one that Carr (2003) describes as the 'new parochialism'. For Carr, the practices of social control are increasingly less likely to be either formal or informal in their pure form. Rather, manifestations of social control tend to rely upon an intersection between formal and informal providers of social control. In a qualitative study of Chicago's Southwest Side, Carr found that collective supervision of neighbourhood youth, a core concept of informal social control, was sporadic at best. Supervision and intervention in disputes was age-graded and confined, for the most part, to familial and personal networks. Parents were too busy working to supervise their children, and neighbours were afraid or unwilling to fill the void. The practices of informal social control in 'Beltway', as he called the neighbourhood, were organised mainly around Chicago's community police programme, the Chicago Alternative Police Strategy (CAPS). CAPS provided neighbourhood residents with ties to local politicians, the police, the judiciary, and the city bureaucracy, strengthening the capacity of the community to defend its local interests. Rather than intercede directly in neighbourhood disputes, residents brought their complaints to CAPS meetings, where the police and other city agencies were recruited to solve community problems.

Given the nature of today's society in which both parents work, some holding two jobs, it is only logical to expect a decrease in informal social control in community areas. Additionally, people no longer tend to live in extended family groups. Brothers and sisters, aunts and uncles, and nieces and nephews no longer live in the same town, let alone on the same block. And people no longer work in the same neighbourhood where they live. Nor do all children attend neighbourhood schools thanks to desegregation, access to excellence programmes, and the desire to attend private schools. All of which have had a dramatic impact on routine activities, which directly affects informal social control at the neighbourhood level. What appears to have replaced these associational ties as a form of social control, at least in Chicago's Beltway neighbourhood, is community policing. Community policing allowed neighbourhood residents to address problems of disorder and crime by securing ties to public officials and the police. Velez (2001) had similar 
findings. Analysing data from the 1977 Police Services Survey (Ostrum et al., 1977), Velez found that a neighbourhood's ability to secure external resources was directly correlated with crime and victimisation.

Studies relating satisfaction with the police to increased social control, and the idea that a new parochialism is emerging in community areas, should be good news for community policing advocates. Both validate the importance of community policing programmes for law enforcement effectiveness. Surprisingly, however, police seem to be moving in a new direction. Community policing is evolving. The influence of broken windows policing has overwhelmed the community implant hypothesis. In fact, it appears that technological innovations are pushing police into a totally new law enforcement paradigm based, in part, upon the computer-generated analysis of crime. Integrated problem solving, strategy development, and intense managerial oversight, as evidenced by New York's Compstat programme, appear to be the basis of a new model of policing focusing on crime and disorder. Compstat is a strategic management process that uses computer-generated data, flexible operational strategies, and supervisory accountability to manage the occurrence of crime and disorder. Walsh (2001) identified four principles that form the basis of the Compstat programme: (1) accurate and timely information about crime; (2) rapid and focused deployment of personnel; (3) effective managerial tactics; and (4) relentless follow-up and assessment.

The Compstat model has been adopted by a number of police departments, including Detroit, Philadelphia, and Chicago. In Chicago it is known as 'DOC,' short for Deployment Operations Center. DOC places computer-generated crime information in the hands of managers so that they can make strategic deployment decisions based on where violent crime is taking place. A 100-officer task force, known as the Targeted Response Unit, comprising specially selected and highly motivated officers, is deployed to specific locations throughout the city based on the intelligence information generated by a daily DOC analysis. In 2005, the Chicago Police Department attributed a $7.1 \%$ decrease in crime to the introduction of this new technology in conjunction with increased camera surveillance and community feedback (Chicago Police Department, 2005).

This new police paradigm has come to be known as intelligence-led policing (ILP). ILP is the collection of information to produce an intelligence-based end-product designed to inform police decision makers at both the tactical and strategic 
levels. It is a model of policing in which intelligence about crime serves as a guide to operations. ILP has been described as a new dimension of community policing in that both rely on information management, two-way communication with the public, scientific data analysis, and problem solving (Carter, 2004). It is built on the argument that the trusting relationships developed between patrol officers and the community can be used to gather information about crime. It is envisioned that the information collected by community police officers will not only concern crime and disorder, but also criminal enterprises and terrorism. In fact, much of the interest in intelligence-led policing has been generated by both the FBI and the Department of Homeland Security as part of their antiterrorist campaigns. What this really means is that community police officers will be encouraged to develop informants in immigrant communities, especially Islamic-American communities, in order to further what has been described as 'terrorist-oriented policing' (Kerlikowske, 2004).

The focus of community policing on crime control and order maintenance is not surprising. Soft policing is hard! Given the choice of computer-driven law enforcement or community building, it is no wonder that police have chosen the more familiar path of crime fighting, even if it involves increasingly criminalising minor offences. Asking law enforcement officers to control crime by building stronger informal relationships with the people in the communities they serve has been a difficult concept for the police to grasp. In fact, putting officers in direct contact with citizens in the hope of fashioning solutions to community problems runs contrary to the professional model and recent police culture. In addition, the idea at the core of community policing of returning to foot patrol and the cop on the beat cannot be accomplished without expending extraordinary resources. In essence, we would need two police departments: the first consisting of a series of neighbourhood foot patrols overlapped by a second group of motorised officers to respond to calls for service. The mission of the first would be informal social control, while the second would engage in traditional police practices.

Such a system exists in Japan. Probably the most successful example of informal social control on the part of police is the Japanese Koban system described by Bayley (1991) in his book, Forces of Order. The Koban or 'police box' is simply a police substation. There are approximately 1,000 Kobans in metropolitan Tokyo. Japanese police are addressed by the public as 'Omawari-san' (Mr Walkabout), and that is just what many of 
them do. What the foot officer does is demonstrate the existence of authority, correct minor problems, and generate trust through the establishment of familiar personal relations with neighbourhood inhabitants. The importance of the Koban system for community policing is that it makes the police familiar in neighbourhoods and thereby increases their approachability. It offsets psychological distance, thereby reducing anxiety, by creating a setting which is intimate, permanent, and small in scale.

The Koban itself not only acts as an outpost where police reports can be made, but also as a community service centre providing police assistance in any number of government-related activities; much like the system of community policing advocated in the United States. The Koban system, however, is not all public relations. Koban officers patrol their neighbourhoods on foot and respond to radio calls as well. They look for people who appear out of place or furtive. They give special attention to loitering males, look for runaway adolescents, and watch for loitering prostitutes. Forty per cent of the criminals wanted by the police in Japan are discovered by patrolmen on the street during the course of their routine foot patrols. This activity is very important to the Japanese police, who have regional and national contests each year to give recognition to the officers who are best at it. The Koban system is not restricted to urban areas, but extends throughout the countryside where police substations are referred to as chuzaisho. To paraphrase Bayley, American police are equivalent to firemen who respond to emergencies; while in Japan, police are like postmen who make daily rounds of low-key activities that relate to the lives of the people in the community.

Would it be asking too much if we sought to realign our policing efforts to mirror the Japanese method? There would certainly be an increased monetary cost. Critics of such a suggestion would undoubtedly point to the differences between Japanese and American society. In particular, they would argue that Japan is a homogeneous society, while America is multicultural. Also, Japan simply does not have the same types of crime problems that exist in the United States. Additionally, American society is built around the use of the automobile and low-density communities are the norm. Would it make any sense to have foot officers patrolling communities where they were unlikely to encounter citizens? Should foot patrol be restricted to high-population-density areas? Although the Newark and other foot patrol studies indicate that foot patrol is an effective police 
strategy, there has never been a long-term analysis of foot patrol's ability to implant informal social control in an American community.

\section{Conclusion}

In the end, it appears that everyone involved in the community policing debate is correct. Social scientists may be correct when they argue that broken windows do not cause crime, but broken windows do cause fear, making order maintenance policing a legitimate pursuit for law enforcement. What is important is the manner in which police conduct their order maintenance activities. Police have been known to be 'dirty workers' (Hughes, 1962) doing 'what they have to do' in order to get the job done through the use (or misuse) of discretion. Research has highlighted the importance of satisfaction with the police. No one likes to be the subject of an illegal police interrogation or search. For police to be successful at order maintenance policing they must simply work within the law. In many ways, order maintenance policing is nothing more than an extension of the professional model. Increasing the number of ordinance violation and misdemeanour arrests is, without any doubt, a bureaucratic practice. We did not need a paradigm shift to accomplish these goals. Nor did we need a paradigm shift to implement the enhanced public relations efforts that are characteristic of community policing programmes. We did, however, need a paradigm shift to recognise the importance of informal social control to police operations.

Working with communities to strengthen their capacity to control aberrant conduct is a new challenge for law enforcement. In fact, such efforts run contrary to the traditional law enforcement model that sought to distance police from the community in order to create impartiality and prevent corruption. As a result, police have encountered some difficulty in their efforts to implement community policing and have been reluctant to provide the resources necessary to establish the networks of foot patrol officers originally envisioned by community policing advocates. As a result, the jury is still out on the community implant hypothesis as originally envisioned. The good news is that Carr's new parochialism may hold the key to the operationalisation of the community implant hypothesis and the realisation of the promise of community policing.

Finally, an often-quoted article in the FBI Law Enforcement Bulletin concludes that we should put to bed the era of com- 
munity policing and engage, instead, in policing utilising the best of what we have learned in the last 20 years (Kerlikowske, 2004). As former police officers, we do not agree. (Yes, both authors were police officers.) Just like so many other officers, we were initially sceptical of community policing, but the record is clear. Community policing holds great promise! What is not clear, however, is how community policing can strengthen informal social control.

\section{References}

Bayley, D. (1991) Forces of Order: Police Behavior in Japan \& the United States. Berkeley: University of California Press.

Bratton, W. and Kelling, G. (2006) 'There are No Cracks in the Broken Windows' The National Review 28 February.

Carr, P. (2003) 'The New Parochialism: The Implications of the Beltway Case for Arguments Concerning Informal Social Control' American Journal of Sociology 108: 1249-91.

Carter, D. for US Department of Justice, Office of Community Oriented Policing (2004) Law Enforcement Intelligence: A Guide for State, Local, and Tribal Agencies. Washington, DC: US Government Printing Office.

Center on Juvenile and Criminal Justice (2002) Shattering 'Broken Windows': An Analysis of San Francisco's Alternative Crime Policies. San Francisco: Center on Juvenile and Criminal Justice.

Chicago Police Department (2005) 'Crime in Chicago Continues Downward Trend through First Half of December'. Press release, Chicago Police Department, 29 December.

Cohen, L. and Felson, M. (1979) 'Social Change and Crime: A Routine Activity Approach' American Sociological Review 44: 588-608.

Corman, H. and Mocan, N. (2002) Carrots, Sticks and Broken Windows. Working Paper 9061. Cambridge: National Bureau of Economic Research.

Finestone, H. (1972) 'The Chicago Area Project in Theory and Practice'. In I. Spergel (ed.), Community Organizations. Beverley Hills: Sage.

Greenwood, P. and Petersilia, J. (1975) The Criminal Investigation Process. Santa Monica: Rand.

Goldstein, H. (1979) 'Improving Policing: A Problem-Oriented Approach' Crime and Delinquency 25: 236-58.

Harcourt, B. (1998) 'Reflection on the Subject: A Critique of the Social Influence Conception of Deterrence, the Broken 
Windows Theory and Order Maintenance Policing New York Style' Michigan Law Review 97: 291-389.

Harcourt, B. (2001) The Illusion of Order: The False Promise of Broken Windows Policing. Chicago: University of Chicago Press.

Hughes, E. (1962) 'Good People and Dirty Work' Social Problems 10: 3-11.

Kansas City, Missouri, Police Department (1977) Response Time Analysis: Executive Summary. Kansas City: Board of Police Commissioners, 23.

Kelling, G., Pate, T. Dickman, D. and Brown, C. (1974) The Kansas City Preventive Patrol Experiment: A Summary Report. Washington, DC: Police Foundation.

Kelling, G. (1981) The Newark Foot Patrol Experiment. Washington, DC: The Police Foundation.

Kelling, G. and Moore, M. (1988) 'The Evolving Strategy of Policing.' In Perspective on Policing. Washington, DC: National Institute of Justice.

Kelling, G. and Coles, C. (1996) Fixing Broken Windows: Restoring Order and Reducing Crime in Our Communities. New York: The Free Press.

Kerlikowske, R. (2004). 'The End of Community Policing: Remembering the Lessons Learned' FBI Law Enforcement Bulletin April.

Kerner, O. (1968) Report of the National Advisory Commission on Civil Disorders. Washington, DC: US Government Printing Office.

Kornhauser, R. (1978) The Social Sources of Delinquency. Chicago: The University of Chicago Press.

Lyons, W. (1999) The Politics of Community Policing: Rearranging the Power to Punish. Ann Arbor: University of Michigan Press.

Mastrofski, S., Worden, S. and Snipes, J. (1995) 'Law Enforcement in a Time of Community Policing' Criminology 33: 539-63.

National Institute of Justice (2002) Satisfaction with Police: What Matters? Washington, DC: US Department of Justice.

National Research Council Committee to Review Research on Police Policy and Practices (2004) Fairness and Effectiveness in Policing: The Evidence. Washington, DC: National Academic Press.

Ostrum, E., Parks, R. and Whittaker, G. (1977) Police Services Study Phase II: Richmond, St. Louis, and St. Petersburg. Washington, DC: National Institute of Justice. 
Police Foundation (1981) The Newark Foot Patrol Experiment. Washington, DC: The Police Foundation.

President's Commission on Law Enforcement and the Administration of Justice (1967) The Challenge of Crime in a Free Society. Washington, DC: US Government Printing Office.

Resig, M. and Parks, R. (2000) 'Experience, Quality of Life, and Neighborhood Contexts: A Hierarchical Analysis of Satisfaction with Police' Justice Quarterly 17: 607-30.

Resig, M. and Parks, R. (2004) 'Can Community Policing Help the Truly Disadvantaged?' Crime and Delinquency 50: 139-76.

Rose, D. and Clear, T. (1998) 'Incarceration, Social Capital, and Crime: Implications for Social Disorganization Theory' Criminology 30: 441-79.

Rosenbaum, D. (1987) 'The Theory and Research behind Neighborhood Watch: Is it a Sound Fear and Crime Reduction Strategy?' Crime and Delinquency 33: 103-34.

Sampson, R. and Raudenbush, S. (1999) 'Systematic Social Observation of Public Spaces: A New Look at Disorder in Urban Neighborhoods' American Journal of Sociology 105: 603-51.

Shaw, C. and McKay, H. (1942) Juvenile Delinquency in Urban Areas. Chicago: University of Chicago Press.

Sherman, L., Milton, C. and Kelly, T. (1973) Team Policing: Seven Case Studies. Washington, DC: The Police Foundation.

Silver, E. and Miller, L. (2004) 'Sources of Informal Social Control in Chicago Neighborhoods.' Criminology 42: 551-83.

Silverman, E. (1999) NYPD Battles Crime: Innovative Strategies in Policing. Boston, MA: Northeastern University Press.

Skogan, W. (1990) Disorder and Decline: Crime and the Spiral of Decay in American Cities. Berkeley: University of California Press.

Skogan, W. (2006) 'The Promise of Community Policing'. In D. Weisburd and A. Braga (eds), Police Innovation. Cambridge: Cambridge University Press, 27-44.

Taylor, R. (2001) Breaking away from Broken Windows: Baltimore Neighborhoods and the Nationwide Fight against Crime, Grime, Fear, and Decline. Boulder, CA: West View Press.

Thacher, D. (2004) 'Order Maintenance Reconsidered: Moving beyond Strong Causal Reasoning' The Journal of Criminal Law and Criminology 94: 381-414. 
Thomas, W. and Znaniecki, F. (1980) 'The Concept of Social Disorganization'. In S. Traub and C. Little (eds), Theories of Deviance. Itasca, IL: F. E. Peacock.

Tronjanowicz, R. Kappeler, V., Gaines, L. and Bucqueroux, B. (1998) Community Policing: A Contemporary Perspective. Cincinnati: Anderson Publishing.

Velez, M. (2001) 'The Role of Public Social Control in Urban Neighborhoods: A Multi-Level Analysis of Victimization Risk' Criminology 39: 837-65.

Walker, S. (1984) 'Broken Windows and Fractured History' Justice Quarterly 1: 77-90.

Walsh, W. (2001) 'Compstat: An Analysis of an Emerging Police Managerial Paradigm' Policing 24: 347-63.

Wilson, J. and Kelling, G. (1982) 'Broken Windows: Police and Neighborhood Safety' Atlantic Monthly 249: 29-38.

Wilson, W. (1987) The Truly Disadvantaged. Chicago: The University of Chicago Press.

Worral, J. (2002) Does 'Broken Windows' Law Enforcement Reduce Serious Crime?. Sacramento: California Institute for County Government.

Xu, Y., Fiedler, M. and Flaming, K. (2005) 'Discovering the Impact of Community Policing: The Broken Windows Thesis, Collective Efficacy, and Citizens' Judgment' Journal of Research in Crime and Delinquency 42: 147-86.

\section{Further Reading}

Miller, D. (2001) 'Poking Holes in the Theory of Broken Windows' Chronicle of Higher Education 47: A14-16. 
Copyright of Police Journal is the property of Vathek Publishing Ltd and its content may not be copied or emailed to multiple sites or posted to a listserv without the copyright holder's express written permission. However, users may print, download, or email articles for individual use. 